\title{
Germán Pardo García, o el Poeta de la Desolación
}

$\mathbf{V}$ ASCONCElos definió a mi patria diciendo que "el lirismo ha salvado a Colombia de la crueldad". Los poetas guerreros y estadistas, forjadores de nuestro pensamiento en guerras y constituciones, demuestran que la libertad virilmente conseguida sólo puede prosperar cuando el sentido romántico de la verdad ha creado el clima vital de la belleza en la poesía. Por algo el poema épico es el troquel en que se han acuñado las civilizaciones.

La alianza de la poesía y de la política no es una casual y esporádica coincidencia, sino el signo que se repite muy particularmente durante el siglo xIx por gracia del romanticismo y de la atmósfera lírica en que vive naturalmente la tierra colombiana.

Luis Vargas Tejada es la definición misma del héroe romántico, que a los veintiséis años de edad se sacrifica por la libertad, conspirando contra el Libertador convertido en déspota. En nadie como en este poeta se define el clima psicológico de la Gran Colombia en sus postrimerías, cuando Bolivar, ya en el ocaso de su grandeza, veía tambalear entre manos empequeñecidas por espurias rivalidades, los nobles y magnánimos diseños que él había trazado para llevar este continente incauto y locuaz a superiores destinos.

José Eusebio Caro y Julio Arboleda, fundadores del partido conservador y de lo que pudiéramos llamar el gran romanticismo colombiano, fueron dos ardientes vidas paralelas. Rafael Núñez, el Regenerador, tan significativo en nuestra historia, como Bolívar, o como Santander, fué un gran estadista y un gran poeta. Su figura enorme y contradictoria, hecha de fuerza y de sutileza, de astucia y de sarcasmo, nos alcanza con el supersticioso y mágico influjo que debió 
de irradiar de su sombra escurridiza como la de un fantasma por la tramoya de su tiempo.

Miguel Antonio Caro, presidente de la república como Núñez, dió a la literatura universal la mejor traducción de La Eneida en la lengua castellana, y a Colombia la Constitución del 86, que, en sus aspectos esenciales, rige todavía los destinos de la república. El último de los poetas de primera magnitud en que conviven la política y la poesía fué Guillermo Valencia, sobre cuyos despojos acaba de cerrarse la tumba entre el llanto de su pueblo de Popayán y de su solar de Belalcázar, que fué el de los Condes de Casavalencia.

Muerto Víctor Hugo y con él la poesía de las crepitantes y suntuosas apariencias, fueron borrándose del ajetreo cuotidiano los poetas estadistas. Ya Bécquer y Verlaine habían esmerilado los resplandores de Hugo, tendiendo un puente hacia el simbolismo; ya la generación de Mallarmé había promulgado los cánones de la nueva poesía, y ya José Asunción Silva, por el proceso de síntesis que caracteriza a América, aprovechando las escuelas presentes y pasadas, había creado el modernismo que más tarde culminó en Darío. Los flamantes discípulos de Hugo emperejilaban aún poemas con el corte anticuado de sus levitas.

Al descubrir la poesía los recintos sonoros interiores, velados al rumboso versificador, y al complicarse la vida colombiana con los problemas contemporáneos, por selección natural fueron deslindándose las distintas expresiones de la individualidad, de tal manera, que los estadistas terminaron por no entender a los poetas.

He aqquí, pues, a los poetas colombianos adelgazados en su reino interior con inefables problemas de belleza que no se cotizan en los mercados de bolsa, y he aquí a los estadistas colombianos metidos hasta el tuétano en la sociología y la economía, para darle a su tierra la actualidad juridica que hoy la distingue como un modelo anericano de democracia. Entre los primeros, Germán Pardo García es el poeta por excelencia, porque vive por la poesía y para la poesía.

E1 mismo se ha definido diciéndome que es un hombre en forma de poeta angustiado. Lo conocí hace veinte años en el abigarrado movietone de la Calle Real de Bogotá. Indiferente al vocerío circundante, se le veía enmarcado en la pterta de una tienda cuando en las mañanas dominicales los parroquianos apuraban el paso para no llegar tarde a la misa de doce. La evocación del poeta adolescente revive en mi recuerdo, ya medio borrosos los personajes que en esos lejanos 
dias formaban en la Calle Real típicas comparsas para una nueva Verbena de la Paloma. Todo ese gentío, prensado en los andenes por los tranvias, era como una serpiente emplumada con el colmillo en la esquina de Arrancaplumas, sede casi única de la chismografía y del proverbial ingenio bogotano.

Germán Pardo García pertenece cronológicamente a la generación de "Los Nuevos", representada en Bogotá por la tertulia irreverente que en el Café Windsor, bajo las barbas nihilistas de León de Greiff y la acertada sensibilidad revolucionaria de Alberto Lleras Canargo, revisaba los extraños postulados filosóficos y estéticos de la postguerra.

Pero nuestro poeta nunca ha sido literato de ensayar posturas para mimetizarse con determinada escuela. Su acto de crear es un trance desnudo y desgarrado, y su lírica siempre se ha mantenido tan distante del arabesco preciosista como del rompecabezas que cultivan los vanguardistas desde el novecientos, con Apollinaire, hasta nuestros días, con Neruda. Tampoco es un poeta de barricada, al servicio de tesis sociales, ni un genio simulador que ande asombrando numerosos y malos imitadores; es lo que se dice un poeta, es decir, el hombre solitario en su colina, que ha sembrado para la posteridad. Su obra es su propia biografía en la removida tierra universal con los tránsitos del amor, de la soledad y de la muerte.

Como todos los grandes poetas tocados por el genio cicloide, Germán Pardo García es un fabricante de fantasmas. El estupor y el terror remueven su clima feraz y en el surco de su angustia crecen como un pavor anochecido sus inefables poemas. En él se cumple la palabra de Sainte-Beuve cuando decía que la personalidad psicológica del escritor se refleja en la obra directamente por confesiones e indirectamente por símbolos. El medio ambiente determina a su turno, de manera inevitable, el psiquismo: Germán Pardo García perdió a su madre cuando contaba él dos años. Su padre, el magistrado Germán D. Pardo, lo confió al cuidado del ama, una mujer extraña y supersticiosa, quien lo llevó de la ciudad al páramo que aparece como una obsesión terrorífica en sus poemas.

En la tenebrosa casa, siempre deshabitada, sólo conoció la imagen del ama, hablándole de ánimas en pena, y el fantasma del páramo aullando como un lobo en el viento de la noche. Lo que pudiera llamarse su temperamento esquizoide, no es, a la luz de estos antecedentes, sino la defensa de su propia vida interior, el acto violento 
y fuerte que ordenó las potencias del espíritu a un superior mandato desde su temprana soledad. No es extraño que en el proceso biológico de asociar imágenes, para formar su sentimiento poético del mundo, el drama telúrico y el ama goyesca hayan poblado de fantasmas la fina y quizá vulnerada sensibilidad que le venía desde las venas de sus antepasados. Así se crió montaraz y refractario a toda sugestión social, y así quedó prisionera su vida entre el complejo de la timidez que linda en muchas ocasiones con el orgullo. Como Leopardi, Germán Pardo García era víctima a los diez años de terrores nocturnos; el mismo diablo los hubiera padecido en la soledad.

Los páramos andinos son melancólicos. La niebla borra los ásperos matorrales que arañan la oscuridad con un horrible traquido de clavijas templando los fúnebres misereres del viento.

El viento del mar es burdo como tna ballena si no se curva en el velamen, o no canta en las jarcias pesqueras como en rústicas arpas.

E1 viento de la montaña mueve rítmicamente los escenarios de encendido plenilunio en que danzan las salvias en flor como mujeres que llamaran con los brazos insinuantes de la primavera.

Pero el viento del páramo es el genio maléfico de la noche andina sincronizado en el mundo vaporoso, pavoroso de los fantasmas. Sigue como un ser invisible a los caminantes, quebrando a su paso ramas e inexplicables voces... El viento del páramo aúlla como un perro en los chiflines y se pasea como un espectro en chancletas por las alcobas vacías. Es el mismo ser que apaga los candiles, que se acerca en puntillas y clava fríos puñales en el terror insomne de los niños. Cuando no está de humor funambulesco, el viento del páramo estremece inmensos bloques de cielo y desencadena huracanes y tempestades sobre los desamparados yermos del corazón y de la tierra.

En el poema "Un viento en los árboles", de Pardo García, está el terror nocturno. No es el viento aldeano que esparce rezos y jazmines al toque de ánimas, sino el viento del páramo que revolotea como un vampiro en la noche:

Un viento sopla, allá sobre los árboles, a la divina luz del plenilunio.

Oigo gemir ese aire y se estremece de asolación mi espíritu.

Mas, no es el viento de la noche. El viento de la noche me ha sido familiar: 


\begin{abstract}
cuando pasa por el jardín, lo siento y hasta mi corazón lo dejo entrar.

$Y$ ahota corro y cierto estremecido las ventanas y escóndome en mi angustia, mientras la vida en el jardín dotmido bajo el terror de un hálito se mustia.

Y un viento sopla, allá sobre los árboles.
\end{abstract}

Todos estos presagios de la angustia podrían parecer novelescos en Germán Pardo García, pero son la historia de su infancia perseguida hasta extremos morbosos por el indecible terror nocturno de las montañas. Cuando murió su padre, tuvo que volver al páramo para cuidar su herencia. Dormía en el mismo inmenso granero donde el viejo señor tenía su alcoba y vivía con su sombra prendida a su soledad. Aun a los veinte años, cuando pasaba por algún paraje donde el ama había visto algún aparecido, le hundía las espuelas al caballo para huir del sitio maldito. Como el "Rey de los Elfos", el poeta oprimía contra el pecho al niño de su corazón para defenderse del genio maléfico de los páramos, y como en la balada de Goethe, el poeta llegaba en su caballo a la casona solitaria con el niño de su corazón muerto de espanto.

En Germán Pardo García están visibles todos los presagios, aun el del caballo negro visto en la noche, símbolo psicoanalítico del pánico y de la muerte. En su poema "Un caballo en la sombra", completa el poeta su patología del terror con los presagios que suelen venir de los astros. Es curioso que la palabra "luna", tan calumniada por los poetas, no aparece siquiera una sola vez en los cantos de Germán Pardo García.

Su terror está, pues, en la noche y en el viento, y es el oscuro barro que ha modelado su vida y su canto. Ahora, cuando atardece su soledad entre las gentes, baja por sus montañas interiores una bruma semejante a las moles inmensas que se posan sobre las estribaciones del páramo, y cuando en las almas páramos cae la bruma, ya nada las renueva. El Páramo del Verjón, en cuyas inmediaciones transcurrió su vida, lo ha modelado a su imagen y semejanza, y ahora lo atrae con extraña fascinación. Huésped huraño entre los hombres, Germán Pardo García volverá al páramo, como vuelven los salmones, para morir, al agua dulce del río donde nacieron. 
Los movimientos afectivos de la cuotidianidad tienen en este poeta un profundo sentido místico, pero todos ellos conducen su ansia de fidelidad a la desolación. El amor en sus poemas es el amor en las más elevadas presencias y en estilo de evangélica sencillez sólo vista ahora en sus Sonetos del convite, que son su Cantar de los Cantares. Ante el uncioso acento de estos versos se siente el mismo recogimiento que silencia al viajero ante las estelas antiguas. Los Sonetos del convite son las inscripciones que no vió Pierre Louys en las Canciones de Bilitis. Isadora Duncan, la de los pies desnudos, los hubiera bailado al són de un coro antiguo: es como una serena voz evangélica en la ruta que va de la Ultima Cena al Monte de los Olivos y tiene a la vez la arcaica y desnuda sencillez de las canciones que modulan las flautas pastoriles junto a las ruinas de los templos paganos.

El amor, desde el hallazgo hasta el olvido, deja apenas la huella de su planta y un vago aroma de sándalo y cinamomo en la morada del convite. Parece desprendido de las estelas que guarda la piedra inmortal en el Museo de las Termas. Raro es el poema de Germán Pardo García, en su primera época, que no pueda grabarse en un epitafio: por ello to he llamado el poeta de las estelas.

El estilo de este joven maestro colombiano es el mínimum de materia con el máximum de expresión. Quizás el páramo sobrio y yermo le dió, con el complejo del terror, la límpida y profunda sencillez del estilo. Pero hay en este prodigio de melodía interior y en esta sabia economía de materia, algo que desconcierta y es su confesado horror por la literatura como búsqueda deliberada de un estilo y como producción en frío a la demanda. A tal extremo llega su inhibición por una literatura de compromiso, que, habiendo sido nombrado académico, declaró su incapacidad de hacer el discurșo si acaso dicha formalidad era imprescindible para el ingreso. En esta aterrada sencillez de hombre huraño, socialmente inhibido, se descubre sin esfuerzo al niño que huía de la gente para esconderse en los matorrales del páramo. Tal percance académico, de tan fino y regocijante humorismo, debería declararse fiesta panamericana, por ser la primera vez que un letrado de la América parlanchina incurre en la elegancia de no poder fabricar un discurso.

Sorprende que Germán Pardo Garcia haya llegado a tal madurez de estilo sin el proceso de buscada ponderación que supone la técnica en el arte. La técnica como realización de forma está unida por 
el extremo más profundo al drama de la creación y por el más visible a la materia que es necesario limpiar de impurezas retóricas para que ascienda como savia viva a la flor del canto. Concibo que Germán Pardo García no sea un poeta que profesa: su acto de crear es algo inevitable como el trance. Por esta suerte de mediumnidad que hace su lenguaje permeable a las voces interiores, el poeta colombiano posee un estilo inconfundible donde la materia es ya, como en Fray Luis, espiritu consustanciado con la idea pura que expresa la forma.

Pero nadie puede sustraerse por completo a las influencias de época y de ambiente. El paso del consciente al inconsciente en lo estético, y del inconsciente al consciente en lo moral y filosófico, hace del hombre una muchedumbre de seres que surcan los caminos de su sangre. En esta elaboración de fuerzas infernales y de claridades celestes, Germán Pardo García devuelve sin saberlo influencias llegadas a sus zonas mentales superiores convertidas en su nobilisima sustancia. Así se explica la lenta evolución que va operándose en él, no tanto en los temas que serán siempre los de su círculo psicológico, cuanto en la expresión poética, que ya asoma renovada en Claro abismo. Siempre aletea ese olor de cera virgen en los místicos follajes, pero en este libro de 1940 despliega la mayor riqueza morfológica que se advierte en las culturas colectivas o individuales cuando la creación pasa de lo arcaico a lo clásico y de éste al barroquismo, en que predonina la técnica, a veces con excesos, ya ligeramente divorciada de las ideas puras.

En la juventud, los desengañados —que son siempre los más finos espíritus - se alejan de la forma por un acto de renunciamiento cuasi místico para remontarse en soledades ascéticas hacia la contemplación de las verdades eternas. En ellos predominan los conceptos abstractos sobre las formas concupiscentes; Germán Pardo García es el poeta de las presencias desencarnadas. Pero en la madurez el hombre se defiende de la ya presentida desintegración retornando desesperadamente a la forma, como Fausto al venderle el alma al diablo por tun instante de juventud, o como los ancianos soñando con las niñas en flor. Por ello Germán Pardo García, en su libro Sacrificio, de 1943, ha retornado a la forma con el soneto alejandrino, cincelado como una joya a la manera de los tetrarcas franceses.

Sus primeros libros: Los júbilos ilesos, Los cánticos, Los sonetos del convite, Poderios y Presencia, deben contener el mundo germinal de nuevas voces en que vive midiéndose el poeta, pero en lo visible 
representan la primera época, que he llamado de las estelas, por la sencillez arcaica del modelado. Claro abismo, en cambio, aparece en 1940 como un libro de transición. En algunos poemas persiste la desnuda emoción cuatrocentista, pero en otros se advierten signos del novísimo ingenio que viene evolucionando desde los franceses del 85 hasta los americanos de ahora. El hombre de las elegías antiguas, instala ahora su desparpajo, y desde una carpa de veraneo, o desde un casino playero, escribe a una mujer:

\footnotetext{
Yo te busco, mujer deshabitada, en un sitio indefenso que no existe. La inmensidad sus litorales viste de brumas que olvidó la madrugada, y el frio de tu voz desmantelada crucifica la sombra que me diste.
}

En estos versos el poeta se expresa como un hombre de mundo 1943, decepcionado de un flirt.

El poeta, habitante de su melodía en sonetos de métrica invariable muy suya, no cambia de preceptivas, como no cambia la escala pentagónica que sube en quenas y ocarinas, con inagotable "riqueza", descle la profundidad abismal del indio hacia la gris melancolía de la puna. Pero ya en Claro abismo, Germán Pardo García suelta al viento barroco de América las amarras del canto, con un vago rumoreo de río mestizo desbordado, como sucede en el poema "Imágenes de la angustia". No es ya el soneto acicalado que borda con hilos de oro rimas y palabras, sino el torrente de alejandrinos sueltos, antípodas de las estelas, que anuncian quizá la nueva métrica de Sacrificio con el soneto maestro retornado a unas nuevas Flores del mal.

Quizá el artista de su inteligencia pueda enriquecer la paleta con obras maestras como las que trae su último libro, pero su verdad poética más profunda está en su desolación, hija del páramo; las tierras altas les dan a sus criaturas el silencio y la melancolía: alli los animales son pequeños, las plantas rastreras y ásperas, los colores inertes. De ahí que la obra del poeta colombiano en su primera época sea de contadas visiones, con la soledad que le canta como un pájaro en la neblina. Cuando el sol despeja la bruma hay también claridades en sus poemas; pero son claridades deshabitadas que infunden tanto pavor como la bruma en que se envuelven los rumores cuasi metafísicos del páramo. 
A pesar de la abreviada partitura de angustia, hay en su obra los más diversos climas poéticos; pero aun en los júbilos y en las presencias se presiente el terror como la tempestad que en las tardes tranquilas enciende los horizontes. Las órbitas poéticas circundan su desgarrada biografía sin formas tangibles de ternura y esperanza; por eso andar sus caminos es llegar a su desolación, que, en "El corazón vacio", es una colina donde el poeta ha trazado los signos de la perpetuidad en la primera época. Sólo es comparable este poema con la oración que suena como el croar de una rana litúrgica a la orilla de la eternidad, sobre el último estertor de los agonizantes:

Porque ya mi corazón es el corazón de nadie. $\mathrm{Y}$ cuando ya el corazón es el corazón de nadie: cuando las manos se buscan hondamente, por juntarse la diestra con la siniestra, en ternuras insondables; $y$ uno siente que sus manos ya son las manos de nadie.

Cuando por el rostro inmóvil invisiblemente caen unas lágrimas eternas que no logran congelarse, y uno siente que esas lágrimas son las lágrimas de nadie.

Cuando la voz que fué de uno concluye por dispersarse $y$ se la llevan los vientos -alma sola, voz errantey uno siente que su voz ya es la oscura voz de nadie; cuando el corazón no se halla ni en sus mismas soledades porque devoró la angustia sus recónditas imágenes, entonces, a dónde ir; a qué sombra desterrarse; cómo llenar lo infinito; con qué vida, con qué sangre, si uno se invoca hacia adentro con amargura, buscándose, 


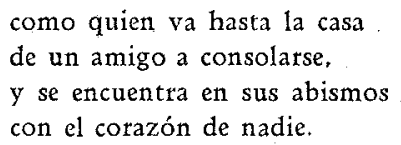

Dicen que Germán Pardo García es un poeta místico, pero Dios no aparece por su nombre en sus cantos. Sólo es místico el hombre que proyecta su destino inmortal en el Universo como espíritu, individualidad o conciencia invulnerable a la desintegración más allá de la muerte. Este poderoso instinto de conservación y de eternidad lo han arraigado desde las más primitivas hasta las más cultas religiones. El cristianismo ha hecho grata a sus fieles la supervivencia en la resurrección de los muertos que han de venir al Valle de Josafat desde el polvo de todos los siglos. Como el destino afectivo del alma es Dios, mientras más concreta sea su imagen más gustada tiene que ser su contemplación para el místico.

Pero el Dios apocalíptico está cada vez más ausente del corazón de los hombres. Su voz es el único milagro atsente de este prodigio de ferocidad que asesina niños y catedrales. Se dijera que su baldía experiencia de la redención, con el beso de Judas y la negación de San Pedro, han dejado en su corazón traspasado por la lanza de Longino, el horror del regreso. Sólo aguardamos, para reconfortarnos, que el Dios inescrutable del Nuevo Testamento vuelva a ser el malhumorado y agreste Jehová que conversaba con su pueblo, trataba de tú a sus profetas y mandaba en picada los ángeles trimotores de la aviación celestial para defender a los inocentes. Pero en esta gran noche de las almas y en la furia desatada, sólo es certeza el resplandor siniestro de los incendios sobre los Cristos mutilados y el grito de los inocentes que claman desde los escombros por la justicia divina.

E1 misticismo de Germán Pardo García no es rezandero y santurrón, ni se extasía en el arrobamiento de Antonio Llanos ni se ensimisma en el ascetismo de Mario Carvajal, otros dos poetas colombianos. Tal vez un Cristo español coagulado y un demonio grotesco murieron en el "corazón vacío" del poeta. Así dice en una de sus elegías:

¿Cómo llamarte, cielo decaído?

Te llamaré diamante ensombrecido;

arco triunfal que nada simbolizas;

espejo sin figuras que agonizas; 
imagen de otra imagen que he perdido.

Vengo a callar al pie de tus derrotas

y de tus subyugados monumentos.

No a estremecer tus estelares ruinas,

ni a desolar el llanto que no brotas,

$y$ que vaga desnudo entre los vientos

de todas tus catástrofes divinas.

Sin embargo, su contacto con el universo poético crea la atmósfera mística inefable que se respira en sus poemas, y su palabra se llena de rocío evangélico cuando habla con voces panteístas de la tierra :

Noble sabor que da de si la tierra.

Sabor a vida y a bondad que vino de su entraña, como un acto divino, simple en la maravilla que lo encierra.

Una noche el diluvio de la sierra mojó los surcos; y en su olor a lino sentí la eternidad de su destino que abre corolas y sepulcros cierra.

Noble sabor a tierra que encontramos en nuestro pan, comido humildemente, sentados en las glebas amarillas, cuando a la tierra en plenitud llegamos, después de caminar inmensamente por nuestros corazones sin orillas.

¿Hacia qué rumbos teológicos orienta su vuelo y cómo individualiza este poeta en su recóndito pudor metafísico las potestades que intuye el hombre en su horror a la desintegración? Su soneto maestro "A la nada" parece llegarnos en su último libro como la voz más reciente de su pensamiento:

Rosa inmisericorde: tu cáliz aparece con esplendor metálico de lívida esperanza.

$T u$ equilibrio en el iris lejano se afianza y la nube en sus fondos de turquesa te mece.

No vives. Eres única. Tu claridad no crece ni disminuye. El día tu plenitud no alcanza, ni la penumbra. Y todo lo que huye y lo que avanza, ante la fría púrpura de tu unidad perece. 
Para tocar tus hojas la delirante mano se inclina sobre el pecho. $Y$ en el calor cercano del pulso, en las arterias, en el misterio mismo de las constelaciones más íntimas, tú callas, y hasta en la sal que riega las soledades, hallas los vértigos que pueden alimentar tu abismo.

Dios parece también una claridad deshabitada en la soledad de este poeta. Quizá cuando en su ruta de Emaus encuentre una divinidad concreta, su desnudez ante la muerte florecerá en un alba nueva y habrá para él otra inmortalidad distinta de la poesía.

Germán Pardo García figura entre los máximos poetas que haya producido Colombia en todos los tiempos. Los páramos andinos sin sol y sin cosechas han sido sin embargo fecundos para los colombianos: de sus plantas rastreras y de sus cumbres ateridas, se destaca este árbol lírico maravilloso, de cuyas flores hará Colombia un nuevo signo de su heráldica. Este hombre, aún joven, es el poeta de la angustia. Su corazón es una cantera de epitafios, pero su reino predestinado es una isla de melodía con la estrella del canto alzándose desde su cisterna hacia la ruta de los ángeles.

\author{
Javier Arango Ferrer, \\ Montevideo.
}

